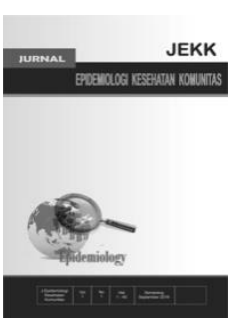

\title{
Faktor Perilaku yang Berhubungan dengan Keberadaan Cimex spp di Desa Purbayasa, Purbalingga Tahun 2021
}

\author{
Dwi Agustin Ronawati*, Retno Hestiningsih*, Nissa Kusariana*, Lintang Dian Saraswati* \\ *Bagian Epidemiologi, Fakultas Kesehatan Masyarakat, Universitas Diponegoro, Semarang
}

\begin{abstract}
Background: Cimex can be found in mattress, sofa, and in places where wood exist. Cimex can cause health effects. Continuous Cimex bites can disturb individual comfort, entomophobia, allergies, and anemia. The existence of Cimex can be influenced by behavioral factors. Cimex is still found in Purbayasa Village. The absence of research on the Cimex survey in Purbayasa Village makes this research necessary to increase public awareness about the dangers of cimex and their prevention. The purpose of this study is to analyze the relationship between behavior and the presence of Cimex.

Methods: This study was a descriptive analytic study used visual survey method with cross sectional approach and a sample count of 53 randomly selected homes in RW 3 . The survey of cimex by visual method. The data was obtained through respondents' interviews with questionnaires and observation sheets with observation. Chi square test is used to analyze the relationship between community behavior and the presence of cimex.

Results: $9.4 \%$ of respondents' houses were positive bed bugs. The founded all bed bugs species is Cimex hemipterus. This study found that $79.2 \%$ of respondents had good knowledge, $75.5 \%$ had good attitudes, $60.4 \%$ had good practices. There was no relation to the knowledge $(\alpha=0.05, \rho=$ $0.225)$. The attitude is related $(\alpha=0.05, \rho=0.000)$. The practice is also related to the presence of bed bugs $(\alpha=0.05, \rho=0.004)$.

Conclusion: It concluded that attitudes and practices are factors related to the presence of bed bugs.
\end{abstract}

Keywords: Behavior Factor; Cimex sp; Presence of Cimex.

\footnotetext{
*Penulis korespondensi,dwiiagustin@gmail.com
} 


\section{Pendahuluan}

Cimex spp adalah insekta penghisap darah, cimex dikenal juga dengan nama Tinggi (bahasa jawa), kepinding, tumbila (bahasa sunda). Adapun dalam bahasa latin, adalah Cimex spp. Tempat persembunyian cimex adalah lipatan kasur, celah kayu, lipatan bantal, di tempat lembab dan gelap yang kurang terkena sinar matahari. ${ }^{1,2,3}$. Cimex bila dibunuh akan meninggalkan bau menyengat yang disebakan sistem pertahanan. Cimex akan bersembunyi saat siang hari pada celah sempit atau retakan kayu, serangga ini aktif di malam hari, menghisap darah saat manusia tertidur. Satu ekor cimex dapat menghisap darah inang selama 10-15 menit. Penelitian Andres et al (2015) Anak-anak dan wanita lebih berisiko digigit kutu busuk yang mungkin terkait ketebalan kult inang. Gigitan cimex akan sangat menganggu kenyamanan karena menimbulkan alergi. Selain itu, gigitan Cimex juga dapat menyebabkan anemia atau kekurangan sel darah merah. Dari dampak kesehatan tersebut dapat dilihat bahwa keberadaan cimex ini perlu dicegah dan dibasmi. $^{4,5,6}$

Di Indonesia, Survey kutu busuk juga pernah dilakukan oleh Didik (2010) di Desa Gebang, Sragen dan diperoleh hasil ada hubungan yang bermakna antara keberadaan Cimex $s p$ pada tempat tidur dengan penurunan kadar $\mathrm{Hb}$ pada responden. Pada Penelitian Fitriatus (2015) diperoleh hasil hubungan yang lemah antara pengetahuan dan praktik terkait infestasi kutu busuk ( $\mathrm{p}=0,000, \mathrm{r}=0,268)$. Penelitian survey kutu busuk yang dilakukan Grace (2017) diperoleh kutu busuk masih dijumpai pada permukiman manado dan sitaro serta morfologi kutu busuk Sitaro memiliki perbedaan dengan kutu busuk dari Manado. ${ }^{7,8,9}$ Menurut H.L Blum, terdapat empat faktor yang memengaruhi derajat kesehatan manusia yaitu : faktor genetika, lingkungan, perilaku, dan pelayanan kesehatan. Blum menyimpulkan faktor perilaku memiliki peranan besar terhadap tingkat kesehatan, faktor perilaku dapat memengaruhi lingkungan, pelayanan kesehatan, dan dapat berpengaruh pada keturunan atau genetika. ${ }^{10}$

Desa Purbayasa merupakan salah satu permukiman yang belum pernah diadakan penelitian terkait cimex, selain itu masih banyak masyarakat menggunakan kasur berbahan kapuk. Keberadaan cimex masih dijumpai di Desa Purbayasa RW 3, 57\% dari 7 rumah yang disurvey pendahuluan masih dijumpai cimex. Cimex ditemukan pada kasur yang berbahan kapuk, pada galar bambu, dan perabot-perabot yang berada di dalam ruangan yang gelap. Selain itu, terdapat $57 \%$ responden yang mengaku jarang menjemur kasur maupun perabot rumah yang terbuat dari bambu atau kayu. Berdasarkan gambaran tersebut, penelitian ini diperlukan untuk meningkatkan kesadaran masyarakat mengenai bahaya kutu busuk terhadap kesehatan serta pencegahannya. Mengingat keberadaan kutu busuk atau cimex ini dapat membawa berbagai macam dampak bagi manusia, termasuk kesehatan. Tujuan penelitian ini adalah untuk menganalisis hubungan faktor pengetahuan masyarakat, sikap masyarakat, dan praktik masyarakat dengan keberadaan cimex di Desa Purbayasa, Purbalingga.

\section{Metode}

Jenis dan rancangan penelitian yang digunakan adalah Deskriptif Analitik dengan metode Survey dan Pendekatan Cross sectional. Populasi dalam penelitian ini adalah seluruh kepala keluarga yang tinggal di Desa Purbayasa Rw 3 sejumlah 125 KK. Sampel penelitian adalah cimex yang diperoleh dari survey rumah responden. Penentuan besar sampel penelitian mnggunakan rumus besar sampel minimal cross sectional dan diperoleh hasil 53. Pemilihan sampel dilakukan dengan teknik systematic random sampling. Teknik sampling tersebut digunakan secara berurutan dengan interval rumah satu dengan rumah selanjutnya adalah 3 rumah. Teknik koleksi sampel menggunakan incidental sampling dimana cimex yang ditemukan saat survey kemudian dimasukan kedalam tabung vial berisikan alkohol $70 \%$ supaya morfologi cimex tetap terjaga untuk keperluan selanjutnya. Dikarenakan kondisi pandemi covid 19 maka proses identifikasi dilakukan dengan peralatan sederhana yaitu menggunakan kaca pembesar. Variabel bebas penelitian ini adalah perilaku masyarakat. Sedangkan variabel terikat adalah keberadaan cimex. Adapun hipotesis penelitian yaitu, ada hubungan antara variabel bebas dan 
variabel terikat. Data sekunder berupa berupa jumlah kepala keluarga. Data sekunder digunakan untuk mengukur populasi dan sampel penelitian sedangkan data primer diperoleh melalui hasil temuan di lapangan. Untuk perilaku pencegahan keberadaan kutu busuk terdiri dari variabel Pengetahuan masyarakat mengenai kutu busuk dan pencegahan, Sikap masyarakat mengenai kutu busuk dan pencegahan, Praktik masyarakat mengenai kutu busuk dan pencegahan.

Baik buruknya perilaku responden ditentukan berdasarkan skor yang diperoleh dari hasil wawancara dengan lembar kuesioner terstruktur.

\section{Hasil}

Tabel 1 Distribusi Karakteristik Responden

\begin{tabular}{lcc}
\hline Karakteristik responden & f & \% \\
\hline Usia & & \\
$26-35$ & 12 & 22,6 \\
$36-45$ & 13 & 24,5 \\
$46-55$ & 20 & 37,7 \\
$56-65$ & 8 & 15,1 \\
Tingkat pendidikan & & \\
Tidak tamat SD & 1 & 1,9 \\
SD & 2 & 3,8 \\
SLTP/Sederajat & 10 & 18,9 \\
SLTA/Sederajat & 38 & 71,7 \\
PT & 2 & 3,8 \\
Pekerjaan & & \\
Ibu Rumah Tangga (IRT) & 41 & 77,4 \\
Buruh & 6 & 11,3 \\
Wiraswasta & 5 & 9,4 \\
Guru & 1 & 1,9 \\
\hline Total & $\mathbf{1 0 0}$ & $\mathbf{1 0 0}$ \\
\hline
\end{tabular}

Berdasarkan tabel 1 distribusi responden berdasarkan kelompok usia tertinggi berada pada kelompok usia 46-55 tahun yaitu sebanyak 20 orang $(37,7 \%)$ dan terendah adalah kelompok usia 56-65 tahun sebanyak 8 orang $(15,1 \%)$. Tingkat pendidikan tertinggi adalah SMA sebanyak 38 orang $(71,7 \%)$ dan terendah adalah tidak tamat SD sebanyak 1 orang $(1,9 \%)$. Distribusi responden menurut pekerjaan tertinggi adalah IRT yaitu 41 orang $(77,4 \%)$ dan terendah adalah guru sebanyak 1 orang $(1,9 \%)$.

Tabel 2 Analisis Univariat Variabel
Terdapat 8 butir soal pertanyaan pengetahuan dengan 4 pilihan jawaban (a,b,c dan d), 10 butir pernyataan sikap dengan 2 pilihan jawaban (setuju dan tidak setuju) dan 8 butir pertanyaan praktik dengan 2 pilihan jawaban (ya dan tidak). Pengetahuan, sikap dan pengetahuan responden dikategorikan baik bila skor $\geq$ median, buruk $<$ median (Sugiyono and Darnoto, 2016). Pengolahan data menggunakan aplikasi pengolah data sedangkan analisis data dengan analisis univariat menggunakan distribusi frekuensi sedangkan untuk analisis bivariat menggunakan uji chi square.

\begin{tabular}{lcc}
\hline \multicolumn{1}{c}{ Variabel } & f & \% \\
\hline Pengetahuan & & \\
Baik & 42 & 79,2 \\
Kurang & 11 & 20,8 \\
Sikap & & \\
Positif & 40 & 75,5 \\
Negatif & 13 & 24,5 \\
Praktik & 32 & 60,4 \\
Baik & 21 & 39,6 \\
Kurang & & \\
Keberadaan cimex & 5 & 9,4 \\
Ada & 48 & 90,6 \\
Tidak Ada & $\mathbf{1 0 0}$ & $\mathbf{1 0 0}$ \\
\hline Total & & \\
\hline
\end{tabular}

Pengetahuan responden terhadap keberadaan cimex tertinggi pada kategori baik sebanyak 42 orang $(79,2 \%)$ dan terendah pada kategori kurang sebanyak 11 orang $(20,8 \%)$. Hasil penelitian mengenai sikap responden terhadap keberadaan cimex menunjukan tertinggi pada kategori positif sebanyak 40 orang $(75.5 \%)$ dan terendah pada kategori negatif sebanyak 13 orang $(24.5 \%)$. Praktik responden terhadap keberadaan cimex tertinggi pada kategori baik sebanyak 32 orang $(60.4 \%)$ dan terendah pada kategori kurang sebanyak 21 orang (39.6\%). Hasil penelitian mengenai keberadaan cimex menunjukan tertinggi pada kategori tidak ada sebanyak 48 rumah $(90,6 \%)$ dan terendah pada kategori ada sebanyak 5 rumah $(9.4 \%)$. 
Tabel 3. Analisis Hubungan Pengetahuan Masyarakat Dengan Keberadaan Cimex

\begin{tabular}{|c|c|c|c|c|c|c|c|}
\hline \multirow{3}{*}{$\begin{array}{c}\text { Pengetahuan } \\
\text { Masyarakat }\end{array}$} & \multicolumn{4}{|c|}{ Keberadaan cimex } & \multirow[t]{3}{*}{ Jumlah } & \multirow[t]{3}{*}{$\%$} & \multirow[t]{3}{*}{$\mathbf{p}$} \\
\hline & \multicolumn{2}{|c|}{ Ada } & \multicolumn{2}{|c|}{ Tidak Ada } & & & \\
\hline & $\mathrm{f}$ & $\%$ & $\mathrm{f}$ & $\%$ & & & \\
\hline Baik & 5 & 11,9 & 37 & 88,1 & 42 & 100 & 0,229 \\
\hline Kurang & 0 & 0 & 11 & 100,0 & 11 & 100 & \\
\hline
\end{tabular}

Hubungan pengetahuan dengan keberadaan cimex menunjukan dari 42 responden yang memiliki pengetahuan baik, terdapat 5 responden $(11,9 \%)$ yang rumahnya terdapat cimex dan 37 responden $(88,1 \%)$ yang rumahnya tidak terdapat cimex. Kemudian, dari
11 responden yang memiliki pengetahuan kurang, seluruhnya tidak terdapat cimex. Berdasarkan hasil analisis uji hubungan menggunakan Chi square, diperoleh nilai $\mathrm{p}=0.229$ yang diartikan variabel pengetahuan masyarakat tidak berhubungan dengan keberadaan cimex.

Tabel 4. Analisis Hubungan Sikap Masyarakat Dengan Keberadaan Cimex

\begin{tabular}{|c|c|c|c|c|c|c|c|}
\hline \multirow[t]{3}{*}{ Sikap Masyarakat } & \multicolumn{4}{|c|}{ Keberadaan Cimex } & \multirow{3}{*}{ Jumlah } & \multirow{3}{*}{$\%$} & \multirow[t]{3}{*}{$\mathbf{p}$} \\
\hline & \multicolumn{2}{|c|}{ Ada } & \multicolumn{2}{|c|}{ Tidak Ada } & & & \\
\hline & $\mathrm{f}$ & $\%$ & $\mathrm{f}$ & $\%$ & & & \\
\hline Positif & 0 & 0 & 40 & 100,0 & 40 & 100 & 0,000 \\
\hline Negatif & 5 & 38,5 & 8 & 61,5 & 13 & 100 & \\
\hline
\end{tabular}

Hubungan sikap dengan keberadaan cimex menunjukan dari 40 responden yang memiliki sikap positif, terdapat 40 responden (100\%) yang rumahnya tidak terdapat cimex. Kemudian dari 13 responden yang memiliki sikap negatif, terdapat 5 responden $(38,5 \%)$ yang masih dijumpai cimex dan terdapat 8 rumah $(61,5 \%)$ yang tidak terdapat cimex. Berdasarkan hasil analisis uji hubungan menggunaakn Chi square, diperoleh nilai $\mathrm{p}=0.000$ yang diartikan variabel sikap masyarakat berhubungan dengan keberadaan cimex.

Tabel 5. Analisis Hubungan Praktik Masyarakat Dengan Keberadaan Cimex

\begin{tabular}{|c|c|c|c|c|c|c|c|}
\hline \multirow[t]{3}{*}{ Praktik Masyarakat } & \multicolumn{4}{|c|}{ Keberadaan cimex } & \multirow[t]{3}{*}{ Jumlah } & \multirow[t]{3}{*}{$\%$} & \multirow[t]{3}{*}{$\mathrm{p}$} \\
\hline & \multicolumn{2}{|c|}{ Ada } & \multicolumn{2}{|c|}{ Tidak Ada } & & & \\
\hline & $\mathrm{f}$ & $\%$ & $f$ & $\%$ & & & \\
\hline Baik & 0 & 0 & 32 & 100,0 & 32 & 100 & 0,004 \\
\hline Kurang & 5 & 23,8 & 16 & 76,2 & 21 & 100 & \\
\hline
\end{tabular}

Hubungan praktik dengan keberadan cimex menunujkan bahwa dari dari 32 responden yang memiliki praktik baik seluruhnya tidak ditemukan cimex, kemudian dari 21 responden yang memiliki praktik kurang terdapat 5 responden $(23,8 \%)$ terdapat cimex dan 16 responden $(76,2 \%)$ tidak terdapat cimex. Berdasarkan hasil analisis uji hubungan menggunakan Chi square, diperoleh nilai $\mathrm{p}=0.004$ yang diartikan variabel praktik masyarakat berhubungan dengan keberadaan cimex. 


\section{Pembahasan}

\section{Keberadaan cimex}

Cimex ditemukan pada $9.4 \%$ rumah responden. Kamar tidur dan ruang tamu merupakan tempat yang paling sering dijumpai kutu busuk saat penelitian. Terdapat persamaan pada seluruh rumah yang positif cimex, yaitu cimex ditemukan pada perabot yang berada pada ruangan tertutup. Ruangan tertutup menyebabkan ruangan tersebut gelap dan lembab. Tempat yang lembab dan gelap menjadikan cimex tumbuh optimum. cimex banyak ditemukan di sela-sela kasur, sela-sela bantal, dan kursi.. Ciri-ciri kasur yang positif cimex, yaitu pada sela-sela kasur atau bantal terdapat banyak bintik-bintik hitam. Bintik hitam tersebut merupakan kotoran cimex. Survey dilakukan menggunakan metode visual dengan memperhatikan permukaan dan celahcelah benda dengan menggunakan senter, kemudian sampel cimex dimasukan kedalam tabung vial berisikan alkohol $70 \%$ supaya sampel awet. Setelah dilakukan identifikasi. Spesies yang ditemukan seluruhnya adalah Cimex hemipterus dikarenakan spesies tersebut dijumpai di daerah tropis seperti Indonesia. Perbedaan ciri morfologi teretak dari bentuk pronotum sesuai dengan teori dalam panduan identifikasi cimex, Stojanovich HD. $P$ and CJ. Bugs : Pictorial Key To Some Species That May Bite Man.(1977). ${ }^{11}$

\section{Pengetahuan Masyarakat}

Menurut Notoatmodjo (2014) pengetahuan merupakan domain penting yang mempengaruhi sesorang untuk bertindak bila pengetahuan individu baik maka akan dikuti oleh tindakan. Pengetahuan dipengaruhi oleh berbagai faktor seperti pendidikan, lingkungan, dan informasi. Penelitian penulis menunjukan sebagian besar responden memiliki pengetahuan kategori baik (79.2\%) sedangkan pada kategori buruk sebanyak (20.8\%). Setelah dilakukan uji chi square, pengetahuan tidak berhubungan dengan keberadaan cimex ( $p$ value: 0.229 ). Hasil penelitian tidak sejalan dengan hasil penelitian Fitriatus (2015) yang menunjukan ada hubungan antara pengetahuan terhadap pencegahan infestasi kutu busuk. Fitriatus (2015) menunjukan $81.8 \%$ responden tidak mengetahui apa itu kutu busuk. Pada penelitian penulis sebagian besar masyarakat sudah mengetahui ciri-ciri cimex serta cara pencegahan cimex paling sederhana. Namun, hampir sebagian responden belum mengetahui cara menghilangkan telur cimex. Telur cimex biasanya ditemukan dalam jumlah bergerombol disertai nimfa-nimfa cimex. Jika sudah menemukan tanda tersebut, ada baiknya dicuci dengan air panas dan rutin menyikat celah perabot supaya telur dan nimfa cimex hilang perlahan. Dilihat dari transmisi, Telur cimex sangat mudah terbawa pada pakaian atau benda yang dibawa oleh seseorang maka cara terbaik adalah dengan menyikat dan mencuci benda menggunakan air panas. Pengendalian fisik dengan cara tersebut perlu dilakukan secara berulang. ${ }^{12,13}$ Faktor lain yang menyebabkan tidak berhubungan adalah tingkat pendidikan dimana pada penelitian penulis sebagian besar merupakan tamatan SLTA $(71.7 \%)$. Selain itu, pengalaman pribadi juga memengaruhi seseorang dalam bertindak.

\section{Sikap Masyarakat}

Sikap tidak dapat dilihat secara langsung, hanya dapat ditafsirkan terlebih dahulu dari perilaku tertutup. Sikap belum merupakan suatu tindakan nyata tetapi masih berupa kesiapan seseorang dan persepsi untuk melakukan reaksi terhadap stimulus yang ada disekitarnya. Sikap menunjukkan konotasi adanya kesesuaian reaksi/respon terhadap stimulus tertentu (Notoatmodjo, 2007). Berdasarkan uji chi square, diperoleh ada hubungan antara sikap dengan keberadaan cimex (p value: 0.000). Hasil tersebut didukung hampir setengah responden (49\%) yang menyatakan kutu busuk bukanlah serangga berbahaya, pada kenyataannya gigitan kutu busuk dalam frekuensi yang lama dapat menurunkan kadar $\mathrm{Hb}$ sehingga berpotensi anemia. Dampak gigitan cimex juga diperkuat dengan penelitian Racheelle et al (2015) menyebutkan bahwa kutu busuk juga menyebabkan gangguan kesehatan mental seperti insomnia, cemas, dan ketakutan. ${ }^{14}$ 
Selain itu terdapat responden yang tidak setuju jika menyikat celah-celah perabot dapat membunuh telur kutu. Persepsi tersebut muncul karena cimex sangat sulit dibasmi meskipun kasur atau perabot sudah dijemur, namun menjemur perabot hanyalah mengusir serangga fase dewasa sedangkan untuk fase telur perlu dibersihkan secara rutin dan berulang.

\section{Praktik Masyarakat}

Praktik seseorang yang didasari oleh penglihatan, kesadaran, dan sikap positif maka praktik tersebut akan bersifat langgeng. Berdasarkan uji chi square, ada hubungan antara praktik masyarakat dengan keberadaan cimex (p value: 0.004). Praktik upaya pencegahan cimex, seperti menjaga kebersihan rumah sudah dilakukan oleh seluruh responden. Hal ini sejalan dengan penelitian Ismail et al (2020) yang menunjukan infestasi kutu busuk paling banyak terjadi pada rumah dengan kondisi sanitasi bagus (29.2) dibanding sanitasi rumah yang sedang $(22.5 \%)$ dan buruk $(26 \%) .{ }^{15}$ Pada penelitian Dewi (2010) menunjukan ada hubungan antara mengganti sprei kasur dengan keberadaan kepinding (Cimex spp). Bagian ujung sprei sering menjadi sarang telur kutu busuk, oleh karena itu jika sudah mengetahui kasur terdapat kutu busuk, sebaiknya sprei kasur tersebut dicuci menggunakan air panas. Pada penelitian penulis, sebagian besar responden sudah mengganti sprei secara rutin. Terdapat persamaan pada seluruh rumah yang terdapat cimex yaitu tidak mencuci sprei menggunakan air panas. Peningkatan suhu yang cepat adalah cara terbaik dalam membunuh cimex di tempat tidur dan sprei. Mencuci dengan suhu air lebih dari $60^{\circ} \mathrm{C}$ diperlukan untuk memastikan setiap tahap kutu terbunuh. Serta mengeringkan dengan pengering adalah metode yang efektif untuk membunuh kutu busuk. Pemanasan pada barang yang terinfestasi akan menyebabkan cimex dewasa keluar menjauhi sumber panas. Jika salah satu perabot di rumah terinfestasi cimex maka ada kemungkinan perabot yang lain juga terinfestasi. Pada penelitian penulis, frekuensi menjemur kasur pada rumah yang terdapat cimex tidak berbeda jauh dengan rumah yang tidak terdapat cimex. Hal ini yang dapat menyebabkan cimex terus menetas dan berkembang biak. Selain itu, perabot lain yang terkena cimex jarang dijemur dikarenakan berat jika dipindahkan dan jika dipindahkan maka cimex bisa jatuh lalu berpindah tempat. Cara yang tepat untuk memindahkan yaitu dengan membungkus terlebih dahulu perabot tersebut.

\section{Kesimpulan}

Berdasarkan data keberadaan cimex dan faktor faktor perilaku masyarakat dapat disimpulkan bahwa faktor yang tidak berhubungan dengan keberadaan cimex adalah pengetahuan sedangkan faktor-faktor perilaku masyarakat yang berhubungan adalah sikap dan praktik masyarakat. Diperlukan upaya pemberantasan yang berulang dan rutin supaya cimex dapat hilang.

\section{Ucapan Terima Kasih}

Terima kasih kepada teman-teman dan seluruh pihak yang telah membantu berkontribusi dalam pengumpulan data.

\section{Daftar Pustaka}

1. Totkova A, Totka A, Sevcikova L, et al. 2019. Problems with the bedbug (Cimex lectularius) in Slovakia. Ann Agric Environ Med. 26: 400-404.

2. P.Masini. 2019. Infestation by the tropical bedbug Cimex hemipterus (Hemiptera: Cimicidae): first report in Italy - PubMed. J. Euro Acad Derma Venerol. Available from: https://pubmed.ncbi.nlm.nih.gov/3141936/ (2019, accessed 10 January 2021).

3. Harlan HJ. 2016. Bed bugs 101: The basics of Cimex Lectularius. Am Entomol . 52: 99-101. 
4. Delaunay P, Pharm D. 2012. Human travel and traveling bedbugs. J Travel Med. 19: 373-379.

5. McNeill C, Jarrett A, Shreve MD. 2017. Bed Bugs: Current treatment guidelines. J Nurse Pract.13: 381-388.

6. Zorrilla-Vaca A, Silva-Medina MM, Escandón-Vargas K. 2015. Bedbugs, Cimex spp.: Their current world resurgence and healthcare impact. Asian Pacific J Trop Dis 2015; 5: 342-352.

7. Sumanto D. 2010. Survei keberadaan serangga cimex $s p$ pada lingkungan rumah tangga dikaitkan dengan kadar hemoglobin penghuni rumah di Desa Gebang Sukodono Sragen. Univ Muhamadiyah Semarang; 1.

8. Shaleha F. 2015. Pengetahuan, sikap, dan praktik mahasiswa di asrama tingkat persiapan bersama Institut Pertanian Bogor terkait infestasi kutu busuk Cemix Hemipterus (Hemiptera: Cimicidae). 1-30.

9. Kalangi G, Tulung M, Salaki C, et al. 2017. Morphological characteristics of bedbugs (Cimex sp) from Manado and Sitaro north Sulawesi, Indonesia Doctoral Students, Departments of Entomology, Graduate Programs University of Sam Ratulangi, Manado, North. Int J Entomol Res. 2 (2): 70-75.

10. Syadidurrahmah F, Muntahaya F, Islamiyah SZ, et al. 2020. Perilaku dan promosi kesehatan: Ind $\mathbf{J}$ Health Promot Behavior. Available from: http://journal.fkm.ui.ac.id/ppk/article/view/ 4004.

11. Stojanovich HD. P and CJ. 2010. Bugs: Pictorial key to some species that may bite man. Available from: https://www.cdc.gov/nceh/ehs/docs/pictori al_keys/bugs.pdf
12. Akhoundi M, Sereno D, Durand R, et al. 2020. Bed bugs (Hemiptera, cimicidae): Overview of classification, evolution and dispersion. Int J Environ Res Public Health. 17: $1-20$.

13. Obella Z, Adliyani N. 2015. The effect of human behavior for healthy life. Majority. 4: 109-114.

14. Ashcroft R, Seko Y, Chan LF, et al. 2015. The mental health impact of bed bug infestations: a scoping review. International J Public Health. 60: 827-837.

15. Alizadeh I, Jahanifard E, Sharififard M, et al. 2020. Spatial distribution of bedbug infestation in infested houses: is there an association between sanitation of houses and bedbug presence? J Environ Heal Sustain Dev. Epub ahead of print 2020. DOI: 10.18502/jehsd.v5i2.3385. 